\title{
"Medusa's Smirk" (1975) by Mihaela Miroiu
}

\author{
Translated from Romanian by Maria Bucur
}

\section{Introduction}

Over the past half decade, philosopher and political scientist Mihaela Miroiu published a series of short autobiographical stories that were eventually collected in a book, $\mathrm{Cu}$ mintea mea de femeie [With my woman's mind] (Bucharest: Cartea românească, 2017), which was reviewed in Aspasia (vol. 12) in 2018. While the whole volume deserves an international audience, I have selected the story "Medusa's Smirk," for translation because it sheds light on a topic little known, yet extremely important, in the lives of many women: sexual violence. Discussing sexual violence was a taboo topic under communism, and many women suppressed their traumatic memories of violence both seen and experienced. Yet accounts such as the one shared below have circulated orally and deserve further attention from scholars. For another relevant account, see http://www.publicseminar.org/2017/12/sex-in-the-time-of-communism/.

The fifth floor of the March Sixth dorm had, like all the others, an open compartment known as "the Pocket." A table with four chairs made of hard plywood. With a tablecloth that looked pretty much like the plastic one in the movie 4 Months, 3 Weeks and 2 Days. ${ }^{1}$ Maybe some days it was used as a makeshift cover for a clandestine abortion, only God and the women who lived there would know those secrets.

The Pocket was the site of many pleasant things during the daytime: manicure sessions, sharing jokes, stories about getting used to the cruel-seductive world of the capital, stories about "patriotic work" in Roseti-Dobrogea, ${ }^{2}$ the place where we also started our experience as college students. In advance of Hegel's The Phenomenology of the Spirit, we learned how to sort red peppers for export, how humid our blankets would get in the IAS barns, ${ }^{3}$ how tasty was the vegetable stew with flies on top, how "brilliant" and devastating it was to have dysentery. We especially learned how to succeed in selecting the funny part of every experience when you were young, especially when retelling it in front of others.

After midnight, the Pocket became the site of secret things. Most often the secret between the reader and her books. That is where we took refuge to study, next to the 
nasty ironing table. Some of us between midnight and 3 am, others more nocturnal, after $4 \mathrm{am}$. The hallway was wonderfully quiet; you could hear the pages turning and pens clanking.

That night I was jubilant. The Pocket was mine alone, in the company of a text about scientific hypotheses (Poincare), from my seminar bibliography. I was arriving at that moment of grace when the text was becoming "mine" and I could understand it from various interpretive perspectives. I got you, I got you! You're mine! The wonderful state of understanding or having the illusion that you understand. What else could I hope for during those hours of sublime solitude?

First I heard the sobs and then her steps. She was running straight toward the end of the hallway. She put her face up against the wall. She started to cry in a small voice, her fist in her mouth. I didn't know what to do. My first impulse was small-minded: "It's her business, she is probably crying after some idiot! I will stay here with my Poincare. I don't even know who she is, really. She's not even in the same school with me." She was one of the dorm celebrities since the Freshman Ball. Miss Freshman. Look at them, boy, these celebs know how to suffer too. But a few seconds later I went to her. I took her in my arms and kept her as closely as I could. For minutes, until she was able to release the wave of tears that she had held back with her mind and fist. I let go a bit, took her by her shoulders and sat her down. I stood behind her, gently caressing the top of her head, in the silence bathed in her mute tears.

I think it was past five in the morning when she quieted down. I didn't say a word during the whole time. Neither did she. Because I didn't want to know what horrible pain brought her there. I was just doing what anyone would do in that situation. But she, I will call her Ana, started to gather her words, first interrupted by fear, but eventually shooting out to liberate her of this terrible secret.

"Right after the Freshman Ball he called me into his office. You know how he is. Harsh, arrogant, strong ... even omnipotent. He invited me to sit down and took my hand.

Pretty, pretty even up-close. Pretty fine. I think we will get along great. What do you say?

I pretended I didn't understand. At any rate, I just didn't want to believe it. That man who pretends to be the guardian of communist morality among students. He grabbed my thigh:

Don't pretend to be stupid!

You know, I am not like that. I have never had a friend like that. Please, let me go.

To hell you're going! You're going to stay here and do as I say.

No, I will never do anything like that."

Ana continued.

"I got up to leave. He pushed me back in the armchair and started to tap with his index finger against my temple.

Yo, stupid bitch! You think I don't know you lied in your admission file? I know everything, you get it? Was your pop in jail for a year? I tell you he was. Did you write that down in the file? No! You lied. You lied because you knew that, if you wrote the truth, you'd be turned down, you couldn't even sit down for that exam that had 24 
candidates for each place. You know what they call that? Perjury. Girl, that is a reason not just for kicking you out, but also sending you to prison.

You can imagine that I went quiet, Mihaela. I was mute, and since November he has been taking advantage of me anytime he wanted, anyway he wanted . . . It was bad enough that I was feeling like a whore. His whore, among others he treated the same way:

Pay in nature, or you'll go to hell!

But I can't stand it any longer. I can't s-t-a-n-d him! I can't. I think I want to kill myself."

I ask, like a fool, the first thing that came to mind, especially given the fears all the girls in the dorm faced at that time:

"Did you get pregnant?

Oh, no. They deal with this immediately. No. It is not that. Since January he's demanded that I linger around other students and report to him about all the bad things they say about the 'socialist order,' of course, about the Party, Ceausescu, about the activists at the University Center. I refused. But he started again to threaten he will reveal my perjury, that thin line I put across the question: 'Do you have relatives who were sentenced for illegal activities?' Starting in February I started to give him some sheets of paper with notations about conversations with other students. Things of no interest to them. He put up with that for a month. Today he called me in again. First he had sex with me, brutally as usual, then he asked:

Let me see, what big accomplishment did you have this week?

I gave him the notebook.

You useless bitch, you are either an idiot, or you are evil, what's this? Who do you think you're fooling? Me?

But that's all they said!

So he got so mad that he started to kick me with both feet, with all his strength. In my stomach. In my ribs. Oh, I thought he was going to kill me. But they don't kill you. They just torture you. They bring you to that point where you hate yourself and you hate your life. I ran as fast as I could. I was afraid to even cry until I got here."

I held her hand until I felt she was falling asleep. That liberating sleep where you find refuge, the episodic death we can luckily find when we lose all hope.

That summer Ana left. She found a foreign citizen beautiful like an aborted fetus, completely unremarkable, but willing to marry her and take her out of the country very quickly. That character disappeared from our lives after we graduated. Others took his place, some mellower and others more horrible.

At the beginning of 1990, his face exploded in front of my eyes, bloviated on the small screen. He was now a hollow figure of democracy and the rule of law. A great guru who was always present among those at the head of the new capitalist and democratic regime, until his death finally liberated me from the horrible nausea I had to live with by keeping my mouth shut about this horrible farce. Medusa's smirk before a history that has so little to do with morality. 


\section{$\diamond$ About the Translator}

Maria Bucur is the John V. Hill Professor of History and Gender Studies at Indiana University, Bloomington. Her recent books include Birth of Democratic Citizenship: Women and Power in Modern Romania (2018), with Mihaela Miroiu; The Century of Women: How Women Have Transformed the World since 1900 (2018); and Gendering Modernism: A Historical Reassessment of the Canon (2017). E-mail: mbucur@indiana.edu

\section{$\diamond$ Author's Notes}

1. This is a reference to the 2007 film by Cristian Mungiu that centers around the sexual violence experienced by young women of the same age as the college students who are the protagonists in this remembrance.

2. A village in Romania.

3. Întreprindere Agricolă de Stat [in English: State Agricultural Enterprise-trans.].

4. This story, like all the others, is entirely factual; I only changed the name of the girl. You might wonder why I kept quiet about that night of terrible secrets, whose silent witness I remained for so many years. Yes, I also asked myself, over and over. I was probably afraid of what would have surely been the consequence of speaking out: being put on trial for slander and then having to pay for it for the rest of my life. He was powerful again. No longer all-powerful, because democracy was on the horizon. I was a nobody, however. Who would have believed me? She had disappeared into the world. The walls are layered with so many nighttime confessions of so many girl-women, that even a person of paranormal powers would not be able to unearth all of them. 